\title{
Saying no (to a story): personal identity and negativity
}

\author{
Tereza Matějčková ${ }^{1,2}$
}

Published online: 15 January 2021

(C) Charles University under exclusive licence to Springer Nature B.V. 2021

\begin{abstract}
The concept of narrativity and narrative identity has two birth certificates: it is linked to the phenomenological tradition-beginning with Arendt's "political phenomenology" - and to the tradition of German Idealism gradually slipping into existentialism. In this article, the author focuses on the latter tradition that helped to pave the way of the concept of narrative self. Key among the thinkers of Classical German Idealism has been Hegel, often considered the philosophical storyteller. Yet the author argues that Hegel's concept of narrativity is not exclusively applied to the self and has hardly any role in the constitution of consciousness. This is the reason why Hegel (rather than thinkers who place the core of personal identity into narrativity) has the means to formulate a more convincing concept of the self and personal identity. The author does not deny that narrativity is seminal, both for leading a life as a human being and as a concrete person; however, originally consciousness and self-hood are born out of negativity. One enacts one's selfhood, once one realizes that one has to interrupt narrativity, step in, refuse to live by it, or just ordinarily rephrase it consciously and by this appropriate it.
\end{abstract}

Keywords Narrativity · Narrative identity · P. Ricœur · G. W. F. Hegel · Promise · Negativity $\cdot$ Personal identity

For all men who say yes, lie; and all men who say no- why, they are in the happy condition of judicious, unincumbered travelers in Europe; they cross the frontiers into Eternity with nothing but a carpetbag - that is to say, the Ego.

Hermann Melville (1993), Letter to Nathaniel Hawthorne

Tereza Matějčková

tereza.matejckova@ff.cuni.cz

1 Institute of Philosophy and Religious Studies, Faculty of Arts, Charles University in Prague,

Prague, Czechia

2 Filosofická fakulta, Nám. Jana Palacha 1/2, 11638 Praha 1, Staré Město, Czechia 


\section{Introduction: Cutting the narrative}

Relying on a loose conception of what narration is, we may claim that all philosophy has a narrative structure. Old questions, themselves plots of sorts, are reconstructed, rephrased and rehearsed in articles and at conferences and in this way partly appropriated in new settings without ever being resolved. Philosophical problems share this trait with myths. There is yet another similarity: myths do not explain, neither do they solve problems. They rather disclose the structure of an experience or a situation, relate it to purportedly eternal schemes and by this very relating of one's unique situation to a general scheme they (may) change the perspective on the given situation and ideally motivate the narrator, or the philosopher, to abandon his or her problem under the pressure of a more urgent but equally unsolvable issue.

The narrative conception of the self is yet another story replaying an old problem formulated in Know Thyself! The imperative points to the specificity of the human self, one of whose options is not being oneself. The exercise of Know Thyself! is, therefore, linked to the art of criticism, of making differences where differences need to be made. In this specific case, this means: to make a difference between the "what" and the "who," and it also means linking the general who to the specific who that is essentially linked to the how. As Axel Hutter has shown in his book Narrative Ontology (2017), Thomas Mann captures this difference in a scene from Joseph and His Sons: Jacob approaches Isaak's tent in order to trick his father into giving him the patriarchal blessing. He introduces himself with the general I: "It is I." To this the blind father responds:

But who are you? Are you not perhaps a thief on the prowl, son of a thief, who has come to my tent claiming 'It is I'? For anyone can claim 'It is I,' but the question is who says it" (2005, $165 \mathrm{f}$.).

Jacob thus answers with his personal I: "It is your son who says I and who has hunted and prepared a meal for you." Upon this, Isaak is reassured and invites the trickster into his tent. Mistreating his father's trust and taking advantage of his blindness has proven productive and it is startling that the author of this story never comes back to this deception, implying that though Jacob was not the one whom the father intended to bless, he was the right one to get the blessing nonetheless. So, Jacob creatively adopted a false identity so that the right person gains the blessing.

My aim is to analyze the concept of narrative identity, considering it as part of the narrative of the history of philosophy or even the philosophy of history. Though my point of orientation will be Ricœur's concept of narrative identity, I want to link this variation of an ancient philosophical problem to related attempts as put forward in the tradition of German Idealism, a constant reference point of Ricœur's thoughts. In several passages, Ricœur reproduces what he calls the "narrative function" in explicitly Kantian terms, describing it as an "art hidden in the depths of the human soul" and calling the function of mediating between being and meaning a "narrative schematism" (Ricœur 2016, 144-155). ${ }^{1}$ Yet Ricœur does not re-appropriate motives only from Kant, but from Hegel as well; and even

\footnotetext{
${ }^{1}$ For an enlightening overview of some of the variations of narrative identity and their respective problems see Čapek (2017, 359-375).
} 
though his relation to Hegel is polemical, he is conscious of the fact that a form of narrativity he himself partly embraces plays a constitutive role in Hegel's œuvre: "As Hegel said, Weltgeschichte ist Weltgericht, like a text human action is open work, the meaning which is in suspense" (Ricœur 2016, 170).

Not only do we encounter a form of narrativity in the tradition of German Idealism, thinkers pertaining to this "genre of thought" came close to formulating the concept of narrative identity. Kierkegaard, himself taking up hints from German Idealism, is often considered the father of narrative identity. ${ }^{2}$ From this perspective, we might speculate that the more or less explicit concept of narrativity and narrative identity may have two birth certificates: it is linked to the phenomenological tradition-beginning with the "political phenomenology" of Hannah Arendt, as Ricœur points out (1983, 60-72) ${ }^{3}$ and to the tradition of German idealism gradually slipping into existentialism.

Why are many thinkers of this tradition inclined to understand the self on the background of individual narration? The tendency might owe primarily to the intersection of self-consciousness, action and the virulence of time, deemed essential for German Idealists. ${ }^{4}$ Despite the fact that Ricœur's criticism of Hegel's overarching narratives, especially of the Prussian state, is well known, an understanding of the relation of Hegel and Ricœur might disclose possible variations of narrativity and might show that Hegel was the less narrative author. In this essay, I want to argue that Hegel's concept of narrativity is not exclusively applied to the self and has hardly any role in the constitution of consciousness. In my interpretation, this is the reason why Hegel, rather than Ricœur, has the means to formulate a more convincing concept of the self and of personal identity.

My aim is to highlight the fact that Hegel refrains from identifying self and narrative self without denying that narrativity is important. While embedding the self into a grand narrative, he does not lose sight of the idea that essentially the individual selfconsciousness is characterized by rupture rather than continuity. Further, Hegel is well conscious of the fact that there is no narration without a narrator but there certainly is self-conscious life without narration. ${ }^{5}$ The dialogue between a Hegelian perspective on identity and Ricœur's conception offers a means to better understand the essentially non-narrative, even bodily and habitual aspects of identity which Hegel repeatedly analysed. In Phenomenology of the Spirit, the self emerges as a real self in the form of bodily striving and desire $(1977,105)$. In other words, self-consciousness and a first

\footnotetext{
${ }^{2}$ In their introduction to Kierkegaard after MacIntyre (2001, xix), Rudd and Davenport point out that Kierkegaard's understanding of the development of ethical personality involves a quest for narrative unity.

${ }^{3}$ Sophie Loidolt reconstructs this Arendtian concept of narrativity in Phenomenology of plurality. Hannah Arendt on political intersubjectivity (2012, 207-212).

${ }^{4}$ Of course, this does not apply only for German Idealists, not even only for philosophers or psychologists. Recently, the physicist Carlo Rovelli (2019) has formulated a narrative conception of the self, not incidentally based on his inquiry into the essence of time. "Every moment of our existence is linked by a peculiar triple thread to our past - the most recent and the most distant-by memory. We are histories of ourselves. Narratives."

${ }^{5}$ If we wanted to claim that independently of narration there is no self-consciousness, no agency, no self, this theory would place the stakes for personality excessively high, which would exclude from the status of persons many individuals whom we might want to credit with self-consciousness. See for instance Lamarque (2004, 393-408): "Narratives are stories that only exist when they are told. Without narration there is no narrative. Yet where there is no narrative it seems illegitimate to infer there is no subject of thought and action."
} 
idea of personal identity is originally nothing but a desire to be oneself when faced with a reality that is always something else in a disturbing or unsettling manner.

In the view of the narrativity-thesis, it is additionally important to note that this bodily foundation of the self fails to have a linear narrative structure. Originally, it is fully preoccupied by the cyclical bodily dimension, by recurring movements and drives. ${ }^{6}$ It is only after this stage, after becoming part of the social realm, that selfconsciousness manages to stretch his or her life- and time-span into a continuum that lends itself to narrativity. Yet Hegel already calls this cyclical consciousness a selfconsciousness and he, further, emphasizes that this bodily dimension of the self never loses its relevance.

Since Ricœur himself emphasizes that the understanding of one's world is the flipside of self-understanding, I want to stress that we learn to know the world and consequently our will and self, first, by experiencing resistance from the outside and, second, by carrying out resistance ourselves and by dissenting to narratives told about ourselves, be it by others or by ourselves. From this perspective, the self is first and foremost the difference that makes a difference. In realizing that I am not the world, I can be in the world, and because I realize that I am not my story, I can elucidate what I consider my story, change it, reinterpret it or abandon it altogether.

What does my Hegelian perspective amount to then? Narrativity is important, both for leading a life as a human being and as a concrete person. However, I doubt that it is as central as suggested in Ricœur's narrativity thesis, and, further, what I miss in this account is the aspect of negativity essential, if not constitutive, of consciousness.

\section{Don't keep your word}

According to Ricœur, our self is not a mere fiction but a substantial one, a fiction with a "support of sameness" (1994, 149). What kind of "support" does he have in mind? To understand this, we must first realize that identity is essentially a practical category. It is neither something given nor something we theoretically learn, but something we do. Identifying someone means answering the question: "Who has done this?" or "Who is the author?" (Ricœur 1988, 246). Some pronounced links between Ricœur and German Idealism may begin to become apparent. Fichte formulates an explicitly pragmatic concept of the I that reaches into the ontology of the self. The I is pure action, in fact its volitional and practical aspect is highlighted by the formulation of a neologism: the self is not only an act, it is a deed-act, a Tathandlung. In this Tathandlung, the I posits itself as a transparent identity with itself, as the I=I (Fichte 1982, 21).

Yet, Ricœur refuses a self-reflexivity that posits its own identity. Precisely against these concepts, he aims his narrativity-thesis, and thus he accounts for the fact that we are simultaneously actors and patients of our deeds. The narrative self is not a Fichtean free-floating Thathandlung, not an infinite pure I, but a "mixture" of self-consciously assigned meaning on the one hand and contingency moulded into coherency on the

\footnotetext{
${ }^{6} \mathrm{Cf}$. Hegel 1977, 109. "Self-consciousness is thus certain of itself only by superseding this other that presents itself to self-consciousness as an independent life; self-consciousness is Desire. Certain of the nothingness of this other, it explicitly affirms that this nothingness is for it the truth of the other; it destroys the independent object and thereby gives itself the certainty of itself as a true certainty, a certainty which has become explicit for self-consciousness itself in an objective manner."
} 
other hand. Thus, even though for Ricœur too the I is fundamentally reflexive, it is reflexive not as related "back" to itself but as related to the other.

In this context, Ricœur formulates what I consider a variation of the Hegelian concept of free self-consciousness as "being with oneself in the other." Both Hegel and Ricœur dismiss the concept of Tathandlung. While for Hegel the self's spiritual structure is mutual recognition, for Ricœur the foundational moment of the self is the act of promising. Of course, a promise is only one among many types of activity characteristic of a self in the form of ipse, but Ricœur mentions that this example is "emblematic" (1994, 123).

Despite significant differences between reflexive and interpersonal conceptions of the self, Fichte and Ricœur emphasize identity as being essentially related to action and both emphasize time. In fact, it is through action that time feeds into the I, and thus subjectification leads to temporalization. The action opens the self to unforeseen consequences of his or her deed and thus naturally any action leads to a chain anticipation and retrospection. In transforming time into narrative, we arrive at making sense of what has happened, and thus: "To construe a story is to transform time into meaning" (Angern 2017, 110). Or as David Carr $(2014,220)$ puts it: "Narrative is an essential feature of human existence by which we humanize and thus deal with time."7

Ricœur does not understand the self exclusively along the lines of the promise and instead focuses on what he calls "character." The character has its foundation in the past - it is a solidification based on past behaviour, the promise is an act opening towards the future, potentially even a negation of one's character. In promising to stand by a certain person, I build anticipation. Of course, this can be said of a character too: the more stable a character is, the more anticipation it builds. Yet, while this type of anticipation is based on sameness, the promise kept is a form of anticipation that is fulfilled by means of an active response of a concrete self. While a character remains the same in re-enacting past patterns of behaviour; a promise, quite on the contrary, initiates a new relationship and with this a new reality: In fact, it might be a selffulfilling prophecy: "We respond to the trust that the other places in my faithfulness." Once I make a promise, it is no one other than me who has the responsibility to keep this word. Ricœur even emphasizes that this vow needs to be answered to, "even if my desire were to change, even if I were to change my opinion or my inclination, I will hold firm" (1994, 124).

This counter-factuality of the promise is the source of the ipse-identity and simultaneously it is its extreme case. Therefore, we have to be cautious to correctly evaluate how the promise relates to narrative. The narrative is "conditioned by a support of sameness" and by contingency and givenness. It is an active participation: the self actively interprets occurrences he or she encounters more or less passively. From this perspective, the promise could not count as a narrative since it is the antidote to contingency; it would thus be correct to call it a "counter-narrative," almost as freefloating as the Fichtean Tathandlung.

\footnotetext{
$\overline{7}$ In Carr's last book Experience and History, narrativity has receded into background in favor of the experience, this concept bridging the gap between retention, presence and protention. Narrativity remains constitutive for gaining access to the past. "My present approach is to take 'experience' to be the mediating term. As we have seen, experience has temporal and structural features that lend themselves to comparison with narrative in the 'literal' sense. But experience can be discussed in its own terms, and does not need this comparison to be understood" $(2014,69)$.
} 
Yet this reading does not seem correct. Every promise bears a moment of contingency - the inclination to change one's mind. Promises bind, tame and bestow a structure on what is essentially uncertain, the future (Ricœur 1983, 51). This tendency conditions the concept of the promise: in fact, the promise lives from being broken. From this perspective, even if the promise does not have a downright narrative structure, it is, so as to say, a script, a backbone of the narrative. ${ }^{8}$ Ricœur considers it the purest level of spontaneity of the personal self: not despite the fact that the promising self makes himself or herself dependent on something beyond his or her control; on the contrary, this ability to take up this essential unpredictability bears witness to spontaneity.

The link between spontaneity and passivity introduces us to the question of Ricœur's narrative ontology, an ontology that is meant to correct errors he discovers in the ontology of the reflexive Cartesian (and Fichtean) tradition. Central is the concept of "intertwining", of "mixtures" or "criss-crossings" or a "dialectic of interweaving" (1988, 246). With these concepts, Ricœur captures a dialectical structure at the core of his ontology attempting to be just to two basic intuitions: both language that opens us to narrativity, imagination and text and perception that opens us to an immediate reality we sense as bodily creatures need to be taken into account.

In emphasizing this type of dialectic, Ricœur attempts to meet the danger of proclaiming everything to be language or discourse. Apparently, he fears that, in being trapped in discourses, a person is easily deluded about the nature of being and is seduced into proclaiming her, purely human, categories to be sovereign over being and her lived time sovereign over the cosmological time. In this sense, he re-iterates that his narrative identity has no such ambition: "It ought not to be said that our eulogy to narrative unthinkingly has given life again to the claims of the constituting subject to master all meaning" (1988, 274).

Yet some have voiced the suspicion that narrative identity is exactly this: a secularization of the individual immortal soul, a self-immortalization of sorts (e.g. Strawson 2008). This criticism does not do justice to the dialectics of Ricœur's conception. Nonetheless, I agree that in his emphasis on promising, Ricœur places the stakes of self extremely high. Taking identity as a denial of change, even of cosmological time, he reintroduces a form of "monological constancy" (Ricœur 1994, 267), even a heroism of keeping one's promise no matter what happens, while on other occasions he harshly attacks subjective heroism as something belonging to "the egotistical and narcissistic ego whose hypocrisy and naiveté the hermeneutics of suspicion have denounced" (1988, 247).

If it is true that the promise, potentially withstanding any change, is the backbone of narrative, it seems that despite professing to be a "spokesperson" of the fragmented self, Ricœur fails to sufficiently consider not so much the fact of the fragmentation but its meaning. He does not deny that any narrative is provisional and incomplete, but if this is the case, he might take into consideration that this tendency of falling apart is not

\footnotetext{
${ }^{8}$ Cf. Ricœur 1994, 124. "In this respect, keeping one's promise, as was mentioned above, does indeed appear to stand as a challenge to time, a denial of change: even if my desire were to change, even if I were to change my opinion or my inclination, 'I will hold firm'. ... This ethical justification, considered as such, develops its own temporal implications, namely a modality of permanence in time capable of standing as the polar opposite to the permanence of character. It is here, precisely, that selfhood and sameness cease to coincide. And it is here, consequently, that the equivocalness of the notion of permanence in time is dissipated."
} 
only a failure, a sign of weakness and passivity, even of animality, but that it might be considered, quite on the contrary, a sign of sovereign strength of the self.

\section{The importance of the non-narratable}

Critics such as Judith Butler have suggested that, originally and fundamentally, selves physically, spiritually and mentally live from others (2005, 3-40). In this sense, an "anonymous narrative," a reflexivity without a self, is prior to my explicit selfknowledge and my ability to narrate my life-story. In other words, the I has been narrated by others long before it learned to narrate itself.

Ricœur consents: "We belong to history before telling stories or writing history" (2016, 257). Yet, staying with the concept of "narrative," it makes more sense to say that we are inheriting and replaying new versions of received narratives rather than enacting new ones. In this case, we change the dominant concept of Ricœur's understanding of narrative and transform it into a thesis propounding that a self is born in the midst of a social and cultural narrative. ${ }^{9}$ Changing the meaning of the narrative in this direction, I would not deny that narrativity is a potent and, as such, anything but innocent force. Still more importantly it is a force beyond rather within our control. ${ }^{10}$

In this context, I want to return to a phenomenon articulated well in the tradition of Classical German Idealism. According to Hegel, selfhood is originally born of negativity. I enact my selfhood, my "who I am," once I realize that I cannot any longer consent to the inherited, even implicit, narratives, that I even cannot consent to versions of collective or familial memory and interrupt this narrative flow, step in, refuse to live by it, or just ordinarily rephrase it consciously and by this appropriate it.

Regarding the link between Ricœur and Hegel, we notice that Ricœur is not far from this conception:

As for the notion of the narrative unity of a life, it must be seen as an unstable mixture of fabulation and actual experience. It is precisely because of the elusive character of real life that we need the help of fiction to organize life retrospectively, after the fact, prepared to take as provisional and open to revision any figure of emplotment borrowed from fiction or from history $(1994,162)$.

\footnotetext{
${ }^{9}$ One of the reasons why Ricœur did not want to take this step and conceive of narratives as cultural rather than personal might be his distanced relationship with Hegel and Hegelians. It is, above all, on the level of cultural narratives that Hegel has reached prominence, and, of course, his Phenomenology is a Bildungsgeschichte and, thus, has an explicitly narrative structure, yet the principal place of the narrative is not the self but society. For Hegel as the author of the Prussian success-story, see Koschorke (2015).

${ }^{10}$ See e.g. Owen (2018), who treats the concept of narrativity and its dangers in an article analyzing Ian McEwan's novels; in them, McEwan develops philosophical arguments about the nature of consciousness, often criticizing narrativity for its delusionary effects. "Again and again, McEwan's novels dramatize the dangers of our irrational, narrative-drunk brains, and show how stories can make them veer from empathy toward something worse. But, having exorcised his doubts on the page, in the end, McEwan trusts fiction to do its mercurial work - trusts that in the final analysis it will produce more empathy than harmful irrationality. In McEwan's hands, the novel may look — in Lukács's phrase - like 'the epic of a world that has been abandoned by God.' But, as Nietzsche saw, banishing God isn't nearly so easy as some of us might like. McEwan's writing has lost God-but there persists in it a difficult, conflicted, secular sort of faith." Galen Strawson occasionally treats McEwan's conceptions of the self, see e.g. Strawson (2018, 31, 218).
} 
Here, the category of retrospectivity, even a form of a retrospective narrative rationality, is seminal. We think "after the dusk," but while Hegel does claim that thinking is post factum, he definitely does not claim that any form of the self is exclusively retrospective and, of course, neither do we live retrospectively. Yet the "provisionality" of the narrative is even more important. This provisionality suggests that the self has the power to negate and so to reconfigure and restructure suggested narratives. In this case, personal identity is a negation of what I am not able or willing to identify with, in Fichtean terms, the I is negation of the Non-I. We are ourselves as long as we realize that we are not one with anything we relate to-identity is that which is different from difference.

Such a conception of identity does not ensue in a simple numerical identity. The I constituting itself against the Non-I needs to have reasons for doing this because the No or the interruption of a narrative is a burdensome activity. In this conception, the self realizes itself to be a self in learning that there is a difference between being a subject and an object, and he or she further learns that as a self he or she needs to actively entertain this distinction. From this perspective, it is difference that is the condition of self-identity and tending to this difference is what makes the difference personal.

Negativity does not exhaust the essence of identity; yet it is on its basis that we learn to actively formulate a positive identity and grow into it by acting in accordance with it. Even if this is so, the "who I am" never stops feeding from the "this is not me." In this sense, a No appears to be a more convincing candidate for an "identity builder" than a positive relation, a "Yes" as incorporated in keeping a promise.

In other words, we need the generality of the I as well as its negativity, expressed phenomenologically in the experience of the "this is not me": the act of negativity makes the general, anonymous I concrete. This "this is not me" often takes on bodily expression, the self becomes a self by actively and bodily delimiting itself from the surroundings. We learn the difference between ourselves and our outer environment by learning that our world never subordinates either to our thoughts or to our body. ${ }^{11}$

Agreement, promise, consensus - carry something dangerous, a shadow of a conflict about to break out. In fact, we promise because we know that breach and infidelity are the norm. This instability is often associated with the inability to transcend the given moment and thus it is linked to a form of animality: the animal, it is assumed, is the hostage to the eternal now. Yet being self-consciously in possession of the moment is something that vitally belongs to human consciousness. In fact, this ability to turn to the moment and thus refuse to be continuous with a narrative is what makes the human being unpredictable, and this unpredictability is one of the crucial differences between man and the animal (though of course, the higher the animal, the lesser the predictability).

From this perspective, the humans draw their dignity from being an eternal "protestant," which is exactly what makes a human being, among other things, apt for telling stories: being inherently unpredictable, one starts anew and is spontaneous. In fact, this human tendency is well portrayed in the most notorious narrative from Western tradition: according to the biblical tradition, originally, man

\footnotetext{
${ }^{11}$ Of course, the body is a potent carrier of protest even once the self transcends his or her purely bodily dimension. We protest with our bodies in hunger strikes, in public assemblies. But while being essential, the key to the I is that it can refuse even its own body, torment it, sacrifice it, make a diet, discipline it. While this bodily dimension of the I cannot be well captured by narrativity, it is important for understanding how the I relates to the objective world.
} 
lives in innocence and a form of un-consciousness, upon this Adam and Eve say No to God's No and only subsequently, upon this breach, God institutes a new bond, a contract with the chosen people. In the beginning, God only talks to Adam and Eve, but he talks with Abraham whom he recognizes as a person after he proved able to say No. Being able to say No, being a person, and being a potential partner of dialog and of contract is essentially related.

In decisive ways, social and historical narratives constitute who we are-as men or women, children or adults, people of color or white people, people belonging to a sexual minority or majority. A substantial form of identity is secured by these categories, even enforced and supervised by law. But our personal selfhood stems from our ability to appropriate, modify or refuse these suggested ways of being this concrete individual in favor of being a concrete person. In this way, social norms support one's subjectivity precisely because they never fully lend themselves to full appropriation, and as such they offer stability since they always remain partially foreign and nonsubjective in Hegel's expression - they remain "substantial" which means they are not at our subjective disposal.

Would this conception be an adequate response to Ricœur's conception of identity? As I see it, he would disagree. He might immediately object that I failed to consider the most vital aspect he is interested in. Personal identity is based on a specific form of permanence, the stability of selfhood. Can my conception offer this form of a stability? What kind of stability pertains to the "protestant" human being?

The only stability that I see is the stability of the social category on the background of which the subject exercises his or her spontaneity in questioning or in accepting any given norm. Our memory, bodily sameness and social stability might be the only support offered to our selfhood. Yet, above all, I suggest that stability is not that which is an essential mark to selfhood. A banal example is illustrative: accepting mainstream social norms offered by a concrete society often means that one more easily builds a long-term identity, an understanding of "who" one is, an identity that even lends itself easily to a narrative. On the basis of its inherent givenness, I would rather place this form of a "narrative" on the side of idem. Narrative identity is from this perspective an identity that is one aspect, an important aspect, of how we understand ourselves, but it is less on the side of effort and activity than Ricœur suggested.

In the case of personal identity, what takes more effort than sustaining continuity is the ability to break continuity. In this context, I would dispute the cliché according to which it is always easier to build than to destroy. At least in the case of identity this is not true: to rid oneself of an identity imputed by others, by society, even by myself (while I am feeling that this may not be me) is an immensely difficult task. Questioning social norms (or simply not taking them for granted) can ensue in a profound destabilization, even in a collapse of any form of a previous self-understanding. Unless this aforementioned destabilization results in a bodily collapse as well, it may lead to a new self-understanding; this self-understanding, however, need not take the form of a narrative but may be-to use Galen Strawson's expression- “episodic." This "episodicity" (2008, 189-208), this newness born from the rupture might even be considered a better proof of one's ability to be oneself and free than a narrative one attempts to live up to.

Ricœur is right in claiming that selfhood is based on an examined life, on "Know Thyself," but I consider this selfhood to form in a dialogical relation with one's social 
conception of identity. Consequently, personal selfhood is based on the dialectic of socially given narrative identity (a form of idem-identity) and one's active, often ironic relation to it (ipse).

Ricœur captures the strength and weakness of the narrative conception of personal identity with its ambivalent relation of prescription and description in a rhetorical question:

How, indeed, could a subject of action give an ethical character to his or her own life taken as a whole if this life were not gathered together in some way, and how could this occur if not, precisely, in the form of a narrative? $(1994,158)$

I am not saying, as Peter Strawson does, that to gather one's life together is a bad idea, yet, I would leave this "gathering up" to others to do. My own identity arises from a dialectic of the narrations that others tell about me-parents tend to be very eloquent storytellers of our past. First we are parts of our parent's stories and only gradually emancipate ourselves from this position. In other words, constituting my story is essentially conditioned by breaking out of someone else's story, and, what is important as well, I won't live to the end of my own story, which is also something that does not make myself the storyteller of my life, as many critics of narrativity have pointed out. ${ }^{12}$

Essentially, we are not storytellers but protestants. In fact, the "here I stand" as an opponent is a gesture that I take to be a powerful identity-builder and thus resistance is central to the self. A self cannot purely be itself to the extent that it is always thrown and entangled in relations with other objects. Therefore, first and foremost, a self has a training in resistance. I am not saying that the view of others and their stories, into which I am born, are irrelevant. They are extremely relevant, they are one of the conditions of my self since it is only in regard to these stories that I can say: this indeed is me, but it is not all there is to me. Taking up the vocabulary of the German Idealists: it takes a lot of not-I to be an I.

\section{Conclusion}

This experience of negativity is what makes a consciousness a consciousness. Even if we accept and consent to the identity of ourselves constituted by others, it is the essence of consciousness to feel that something is not right after all. "We'll always be troubled by how things are - that's how it stands with the difficult gift of consciousness," as Ian McEwan nicely puts it in his novel Nutshell $(2016,36)$. We are never one with how others perceive us or how they constitute us. This does not mean that we gain authenticity if we evade any form of external attribution, retreating to a solus ipse, since personal identity bestowed by others is indeed an important aspect of human consciousness that is not complete without personal identity. Without it, there would be no Bildung and no creativity, but the most intimate realm is consciousness' negativity, which is a realm that is, at the same time, void, and therefore, once again, identity constituted by others is central.

\footnotetext{
$\overline{{ }^{12} \text { For a survey of this objection, see Stokes }(2015,65-68) .}$
} 
In living in the positive, consciousness transforms this positivity into something that becomes, into something that becomes an evolution, it itself is something that evolves. It formulates this evolution as stories but once these stories are told, they need to be retold. They are essential for self-understanding, but not only as to the content but as to the form: anything positively said, invites a creative repetition. Once one repeats something, one realizes that something is missing without necessarily knowing what is missing. Thus one repeats it from another perspective. In this sense, identity is based on a sequence of undermining repetitions. Self-consciousness seeks the negative, the absent, but lives in the positive.

Acknowledgements The author gratefully acknowledges that this work was supported by the Czech Science Foundation, financing the project "Personal Identity at the Crossroads: Phenomenological, Genealogical, and Hegelian Perspectives" (GAČR 18-16622S).

Funding This work was supported by the European Regional Development Fund project "Creativity and Adaptability as Conditions of the Success of Europe in an Interrelated World" (reg. no.: CZ.02.1.01/0.0/0.0/ 16_019/0000734).

Open Access This article is licensed under a Creative Commons Attribution 4.0 International License, which permits use, sharing, adaptation, distribution and reproduction in any medium or format, as long as you give appropriate credit to the original author(s) and the source, provide a link to the Creative Commons licence, and indicate if changes were made. The images or other third party material in this article are included in the article's Creative Commons licence, unless indicated otherwise in a credit line to the material. If material is not included in the article's Creative Commons licence and your intended use is not permitted by statutory regulation or exceeds the permitted use, you will need to obtain permission directly from the copyright holder. To view a copy of this licence, visit http://creativecommons.org/licenses/by/4.0/.

\section{References}

Angern, E. (2017). Sein Leben schreiben. Wege der Erinnerung. Frankfurt a.M.: Klostermann.

Butler, J. (2005). Giving an account of oneself. New York: Fordham University Press.

Čapek, J. (2017). Narrative identity and phenomenology. Continental Philosophy Review., 50(3), 359-375.

Carr, D. (2014). Experience and history. Phenomenological perspectives on the historical world. Oxford: Oxford University Press.

Davenport, J., \& Rudd, A. (2001). Introduction. In J. Davenport, \& A. Rudd (Eds.), Kierkegaard after MacIntyre. Essays on freedom, narrative, and virtue (pp. xvii-xxv). Chicago: Open Court.

Fichte, J. G. (1982). The science of knowledge, with the first and second introductions. Ed. and trans. Peter Heath and John Lachs. Cambridge: Cambridge University Press.

Hegel, G. W. F. (1977). Phenomenology of spirit, translated by Arnold V. Miller. Oxford: Oxford University Press $(=P S)$.

Hutter, A. (2017). Narrative Ontologie. Tübingen: Mohr Siebeck.

Koschorke, A. (2015). Hegel und wir. Berlin: Suhrkamp.

Lamarque, P. (2004). On not expecting too much from narrative. Mind \& Language, 19(4), 393-408.

Loidolt, S. (2012). Phenomenology of plurality Hannah Arendt on political intersubjectivity. New York London: Routledge.

Mann, T. (2005). Joseph and his sons. New York - Toronto: Alfred A. Knopf.

McEwan, I. (2016). Nutshell. London: Penguin.

Melville, H. (1993). Letter to Nathaniel Hawthorne. In L. Horth (Ed.), Correspondence, edited by Lynn Horth (pp. 184-187). Evanston and Chicago: Northwestern UP and the Newberry Library.

Owen, M. M. (2018). Can there be an atheist novel? The Point. https://thepointmag.com/2018/criticism/canthere-be-an-atheist-novel-ian-mcewan. Accessed 6 April 2020.

Ricœur, P. (1983). Action story and history. On re-reading The Human Condition. Salmagundi, 60, 60-72. 
Ricœur, P. (1988). Time and narrative, vol. 3: Time Narrated. Trans. K. Blarney - D. Pellauer. Chicago London: University of Chicago Press.

Ricœur, P. (1994). Oneself as another. Trans. K. Blamey. Chicago - London: University of Chicago Press. Ricœur, P. (2016). Hermeneutics and the human sciences. Cambridge: Cambridge University Press.

Rovelli, C. (2019). The order of time. London: Penguin.

Stokes, P. (2015). Narrative holism and the moment. In J. Lippitt \& P. Stokes (Eds.), Narrative identity, and the Kierkegaardian self (pp. 65-68). Edinburgh: Edinburgh University Press.

Strawson, G. (2008). Against Narrativity. In Real materialism and other essays (pp. 189-208). Oxford: Oxford University Press.

Strawson, G. (2018). Things that bother me: Death, freedom, the self, Etc. New York: New York Review Books.

Publisher's note Springer Nature remains neutral with regard to jurisdictional claims in published maps and institutional affiliations. 